\title{
IMPLEMENTASI PROGRAM SEKOLAH RAMAH ANAK DALAM MEWUJUDKAN KOTA LAYAK ANAK DI KOTA BATU
}

\author{
Beny Sutami; Dody Setyawan; Noora Fithriana \\ Program Studi Administrasi Publik, FISIP, Universitas Tribhuwana Tunggadewi \\ Email: benysutami@gmail.com
}

\begin{abstract}
Abstrak: Implementasi Program Sekolah Ramah Anak merupakan salah satu indikator capaian Kota Layak Anak sebagai upaya pemenuhan hak dan perlindungan anak di pendidikan. Pemenuhan hak anak merupakan suatu konsep yang dibuat oleh Pemerintah sebagai suatu strategi dalam menentukan indikator-indikator hak anak dalam Sekolah Ramah Anak. Untuk itu diperlukan pembangunan dan sumber daya Pemerintah untuk mendukung setiap upaya yang bertujuan menjamin pemenuhan hak dan perlindungan anak. Penelitian ini bertujuan untuk mengetahui implementasi Program Sekolah Ramah Anak beserta faktor pendukung dan penghambat. Penelitian ini menggunakan metode penelitian kualitatif dengan pengumpulan data melalui observasi, wawancara, dan dokumentasi. Penentuan informan dilakukan dengan menggunakan snowball sampling. Analisis data dilakukan melalui tahapan pengumpulan data, penyajian data dan penarikan kesimpulan. Hasil penelitian menunjukkan bahwa pelaksanaan Program Sekolah Ramah Anak dalam mewujudkan Kota Layak Anak di Kota Batu belum berjalan dengan baik. Beberapa indikator meliputi sosialisasi yang tidak konsisten, ketersediaan sumber daya manusia, anggaran, peralatan yang minim, partisipasi Sekolah untuk terlibat sangat rendah dan lemahnya koordinasi dan kerjasama antar pemangku kepentingan dan pelaksana kebijakan. Faktor pendukungnya meliputi kesepakatan/komitmen Daerah menuju Kota Layak Anak dan aturan yang mendukung tegaknya perlindungan anak. Faktor penghambatnya yaitu sosialisasi tidak konsisten, minimnya sumber daya, rendahnya partisipasi Sekolah dan lemahnya koordinasi antar pemangku kebijakan.
\end{abstract}

Kata Kunci: Implementasi; Kota Layak anak; Program Sekolah Ramah Anak

Abstract: The implementation of Child Friendly School Program is either achievements indicator to City worth child as an effort to fulfill children's rights and protection in education. Fulfilling children's rights is one concept that created by the Government as a strategy to determine children's rights indicators in Child friendly School. Therefore, development and government resources are needed to support every aimed effort at ensuring the fulfillment of children's rights and protection. The purpose of this research is to determine the implementation of Child friendly School Program with supporting and inhibiting factors. This study uses qualitative research methods by collecting data through observation, interviews, and documentation. The determination of informants is using snowball sampling. Data analysis were carried out through the stages of data collection, data presentation and drawing conclusions. The results showed that the implementation of realizing Child friendly School Program in City Worth Childof Batu City was not going well. Some indicators include inconsistent socialization, unavailability of human resources, budget, minimal equipment, low participation of schools, weak coordination and also the cooperation between stakeholders and policy implementers. Another supporting factors include regional agreements/commitments towards City Worth Child and rules that support the protection of children. The inhibiting factors were inconsistent socialization, lack of resources, low school participation and weak coordination among the policy makers.

Keywords: Implementation; City Worth Child; Child friendly School Program 


\section{PENDAHULUAN}

Pendidikan merupakan hak yang harus diperoleh setiap warga negara, termasuk anak-anak. Pendidikan merupakan sarana untuk mengembangkan minat dan bakat siswa sesuai dengan potensi yang dimilikinya. Hal tersebut ditegaskan pada Undang-Undang Dasar tahun 1945 pasal 28C setiap orang berhak mendapat pendidikan dan manfaat dari ilmu pengetahuan dan teknologi. Ketentuan tersebut juga diperkuat dengan pasal 9 ayat 1 Undang-Undang Perlindungan Anak yang menyebutkan bahwa setiap anak berhak memperoleh pendidikan dan pengajaran.

Pengembangan bakat dan minat anak tidak dapat dilakukan dengan optimal tanpa adanya dukungan yang baik dari lingkungan sekitar, baik lingkungan keluarga, sekolah, Pemerintah, maupun masyarakat. Lingkungan sekolah merupakan faktor yang memiliki andil dalam pemenuhan hak anak. Dalam hal ini tentu harapannya sekolah dapat memberikan layanan yang baik kepada anak demi berkembangnya anak secara optimal. Di Indonesia kekerasan terhadap anak menjadi permasalahan serius, permasalahan ini dibuktikan dari data Komisi Perlindungan Anak Indonesia (KPAI, 2018) bahwa sekitar 50\% kekerasan terhadap anak terjadi di lembaga pendidikan.

Permasalahan terkait dengan kekerasan terhadap anak juga terjadi di Kota Batu khususnya. Seperti dilansir dari pemberitaan media online (https://radarmalang.id, 26 Maret 2019) menyebutkan bahwa kekerasan terhadap anak di Kota Batu meningkat drastis. Pada tahun 2017 korban kekerasan terhadap perempuan dan anak berada di angka 9 orang, hingga pada akhir tahun 2018 naik menjadi 31 kasus. Salah satu efek dari perilaku kekerasan terhadap anak adalah perkembangan pribadi, bakat, kemampuan mental dan fisik anak menjadi tidak maksimal. Menindaklanjuti permasalahan tersebut, Pemerintah Kota Batu telah berkomitmen mencegah dan meningkatkan perlindungan terhadap anak di bidang pendidikan melalui kebijakan Sekolah Ramah Anak yang disepakati oleh Kementerian Pendidikan Nasional dan Kementerian Pemberdayaan Perempuan dan Perlindungan Anak. Tujuan dari dikeluarkannya kebijakan Sekolah Ramah Anak tersebut adalah memenuhi, menjamin dan memastikan satuan pendidikan mengembangkan minat, bakat dan kemampuan anak.

\section{Implementasi Kebijakan}

Implementasi adalah tahapan proses kebijakan publik (public policy process) sekaligus kajian yang krusial. Bersifat krusial karena sebaik-baiknya kebijakan, jika tidak dipersiapkan dengan baik penerapannya maka sasaran kebijakan tidak terwujudkan (Widodo, 2017: 85). Pelaksanaan kebijakan akan menjadi efektif apabila berjalannya sesuai standar yang ditetapkan (Edward III dalam Nugroho, 2014: 636)

Pertama, komunikasi kebijakan. Menurut Edward III (Widodo, 2017: 97), komunikasi kebijakan merupakan penyampaian informasi dari satu pihak (policy maker) kepada pihak lain (policy implementor). Untuk menerapkan kebijakan, instruksi kebijakan yang diberikan harus tersampaikan pada orang yang tepat dengan jelas, akurat dan konsisten (Mutiarin dan Zaenudin, 2014: 38).

Kedua, sumber daya. Menurut Van Metter dan Van Horn (dalam Agustino, 2012: 142), keberhasilan penerapan kebijakan sangat dipengaruhi dengan sumber daya yang tersedia. Keberhasilan pelaksanaan kebijakan sangat ditentukan dari kualitas manusianya. Keseluruhan tahap pelaksanaan kebijakan menuntut adanya kualitas yang baik dari manusia (pegawai) sesuai tugas dan tanggungjawab yang ditetapkan. Selain itu, sumber daya penunjang keberhasilan proses implementasi juga didukung dengan ketersediaan anggaran dan peralatan. Kurang cukupnya sumber-sumber tersebut berarti ketentuan atau aturan-aturan (laws) menjadi lemah, pelayanan yang diberikan tidak memuaskan, dan pengaturan-pengaturan (regulations) yang beralasan tidak akan dikembangkan, Edward III (dalam Widodo, 2017: 104).

Ketiga, disposisi. Keberhasilan pelaksanaan kebijakan tidak selalu dapat diukur dari pelaku kebijakan mengetahui dan melakukannya, tetapi ditentukan seikap pelaksana kebijakan untuk 
melakukan kebijakan secara sungguh-sungguh sehingga tercapai dan terwujudkan tujuan kebijakan, Edward III (dalam Widodo, 2017: 104).

Keempat, struktur birokrasi. Adanya ketidaksesuaian pada struktur birokrasi menyebabkan implementasi kebijakan tidak efektif, Edward III (dalam Widodo, 2017: 106). Struktur birokrasi meliputi susunan organisasi, wewenang, hubungan unit organisasi, dan hubungan antara organisasi dengan organisasi lainnya. Oleh karena itu, struktur birokrasi terdiri dari dimensi standar operasional dan fragmentasi. Standar operasional dalam perspektif ini merupakan perkembangan dari tuntutan internal akan ketepatan waktu, pemenuhan sumber daya serta kebutuhan penyemaan dalam organisasi kerja yang kompleks dan luas. Sedangkan fragmentasi menjelaskan bahwa struktur birokrasi menjadi terpecah-pecah (tersebar) menyebabkan terjadinya ketidakefisienan dan pemborosan.

\section{Kota Layak Anak}

Kota layak anak adalah pembangunan yang terencana dan berkelanjutan pada kebijakan dan program untuk pemenuhan hak dan perlindungan anak (www.kla.or.id). Konsep tersebut dikembangkan sebagai langkah nyata Pemerintah mentransformasi konvensi hak anak (Convention on the Rights of the Child) dalam bentuk kebijakan dan program pemenuhan hak anak.

Pengembangan Kebijakan ini berdasarkan dengan 5 (lima) klaster hak anak yang terdiri dari: hak sipil dan kebebasan, lingkungan keluarga dan pengasuhan, kesehatan dasar dan kesejahteraan, pendidikan, pemanfaatan waktu luang, dan kegiatan budaya, dan perlindungan khusus.

\section{Sekolah Ramah Anak}

Sekolah ramah anak adalah satuan pendidikan dalam setiap perencanaan, kegiatan belajar dan kebijakan menjamin anak terhindar dari kekerasan melalui lingkungan ramah, aman, bersih dan sehat (Peraturan Menteri Pemberdayaan Perempuan dan Perlindungan Anak Nomor 8 Tahun 2014 Tentang Kebijakan Sekolah Ramah Anak).

Tujuan dari Sekolah Ramah Anak adalah: Pertama, menjamin setiap anak terhindar dari kekerasan melalui Sekolah Ramah Anak. Kedua, satuan pendidikan mempersiapkan anak untuk tumbuh dan berkembang menjadi pribadi yang bertanggung jawab.

\section{METODE PENELITIAN}

Penelitian ini menggunakan pendekatan penelitian deskriptif kualitatif dengan maksud melihat, mendeskripsi dan menafsirkan sebuah fenomena dengan gambaran yang terstruktur melalui observasi dan kumpulan dari fakta-fakta yang dikumpulkan guna mengetahui secara lebih jauh permasalahan yang diteliti. Peneliti mengambil lokasi penelitian di Dinas Pendidikan Kota Batu, Dinas Pemberdayaan Perempuan, Perlindungan Anak, Pengendalian Penduduk dan Keluarga Berencana Kota Batu, dan Sekolah Menengah Pertama (SMP) Negeri 02 Kota Batu.

Pengumpulan data primer dalam penelitian ini diperoleh melalui wawancara yang mendalam seperti interpretasi tentang kejadian dan keadaan lokasi penelitian untuk memperoleh data atau informasi mengenai objek yang diteliti. Sedangkan data sekunder diperoleh dari studi dokumen berupa catatan peristiwa seperti tulisan, gambar, atau karya monumental objek yang diteliti. Teknik penentuan informan dalam penelitian ini menggunakan snowball sampling dengan informan: Kasie Pendidikan Menengah sebagai key informant, Kepala Sekolah Menengah Pertama (SMP) Negeri 02 Kota Batu, Koordinator Penguatan Pendidikan Karakter SMPN 02 Kota Batu, Koordinator pelaksana Sekolah Ramah Anak SMPN 02 Kota Batu, Kasie Pengarusutamaan Gender dan Pengarusutamaan Hak Anak dan Staf Bagian Sekolah Ramah Anak.

Dalam penelitian ini, Peneliti merupakan kunci utama yang merencanakan, menjalankan, menganalisis, dan melaporkan hasil penelitian. Proses penelitian diperlengkapi dengan pertanyaan 
tertulis maupun lisan yang disiapkan dan diajukan kepada narasumber untuk mendapatkan informasi yang akurat tentang permasalahan yang diteliti. Selain itu, keberadaan Peneliti tidak terlepas dari catatan lapangan berupa catatan hasil pendengaran, penglihatan dan pengalaman pengumpulan data. Data-data yang sudah didapatkan tersebut dianalisis dengan mereduksi data melalui tahap merangkum dan mengambil hal pokok yang selanjutnya data tersebut disajikan dalam uraian, bagan, hubungan kategori dan flowchart. Sehingga, data dapat dideskripsikan dalam suatu obyek penelitian yang sebelumnya tidak jelas menjadi jelas setelah diteliti. Informasi atau data kemudian akan diuji keabsahannya dengan pemeriksaan melalui teknik triangulasi. Peneliti memerik setiap temuan dengan berbagai pertanyaan dan memeriksanya kembali berdasarkan sumber data. Data yang diperoleh melalui pengamatan langsung diuji kebenarannya dengan hasil wawancara dan data yang diperoleh melalui dokumentasi sehingga informasi dan data yang ditemukan dapat dianggap akurat.

\section{HASIL DAN PEMBAHASAN}

Sekolah Ramah Anak disepakati untuk mewadahi satuan pendidikan di Kementerian Pendidikan Nasional dan Program terkait di Kementerian Pemberdayaan Perempuan dan Perlindungan Anak. Sekolah Ramah Anak dibentuk sebagai tindaklanjut keputusan Kementerian untuk pemenuhan hak anak di satuan pendidikan. Satuan pendidikan sebagai pemberi layanan pendidikan yang secara langsung berhubungan dengan anak-anak dan masyarakat berada dalam koordinasi Kementerian Pendidikan Nasional dan Pemerintah Daerah. Kementerian/lembaga memastikan adanya keamanan, keselamatan, kesehatan untuk tumbuh kembang dan kelangsungan hidup anak selama dalam lingkungan pendidikan.

Pada tahun 2014, Pemerintah Kota Batu me-launching Kota Batu menuju Kota Layak Anak dengan beberapa indikator yang harus dipenuhi, diantaranya adalah pemenuhan pendidikan anak. Mengingat hal tersebut, SMPN 02 Kota Batu berinisiatif membentuk Program Sekolah Ramah Anak untuk mencegah kekerasan kepada anak di sekolah. Hal tersebut sesuai dengan visi dan misi sekolah untuk menciptakan lingkungan pendidikan yang nyaman dan kondusif. Program ini dibentuk dengan berlandaskan pada Undang-Undang Nomor 35 Tahun 2014 Tentang Perlindungan Anak, UndangUndang Nomor 20 Tahun 2013 Tentang Sistem Pendidikan Nasional, Keputusan Presiden Republik Indonesia Nomor 36 Tahun 1990 Tentang Pengesahan Konvensi Hak-Hak Anak, dan Instruksi Kepala Dinas Pendidikan (hasil review Program unggulan sekolah).

Berdasarkan landasan hukum tersebut untuk mengukur keberhasilan penerapan Program Sekolah Ramah Anak di Kota Batu, Peneliti menggunakan teori Edward III (dalam Nugroho, 2014: 636). Masalah utama administrasi publik adalah lack of attention to implementation. Pelaksanaan kebijakan menjadi tidak berhasil tanpa penerapan yang efektif dari pembuat kebijakan. Agar pelaksanaan kebijakan efektif, terdapat empat idikator penting yang menentukan keberhasilan program, yaitu: komunikasi, sumberdaya, disposisi, dan struktur birokrasi.

\section{Komunikasi}

Implementasi sebagai bagian dari kebijakan publik (public policy procces) sekaligus kajian yang krusial. Bersifat krusial karena sebaik-baiknya kebijakan, jika tidak dipersiapkan dengan baik penerapannya maka sasaran kebijakan tidak terwujudkan (Widodo, 2017: 85). Pada kegagalan dari pelaksanaan kebijakan diperlukan hubungan baik antar instansi terkait dengan terjalinnya komunikasi dan koordinasi. Untuk itu, koordinasi yang baik antara pemangku kebijakan sangat menentukan keberhasilan pelaksanaan kebijakan yang telah ditetapkan. Pemangku kebijakan telah melaksanakan jaringan komunikasi terkait dengan pelaksanaan Program Sekolah Ramah Anak. Berikut penyampaian pemangku kebijakan dalam kutipan wawancara: 
Dinas Pemberdayaan Perempuan, Perlindungan Anak, Pengendalian Penduduk dan Keluarga Berencana telah melakukan sosialisasi tentang Sekolah Ramah Anak dan melakukan Training of Trainer (ToT) kepada setiap sekolah dan tenaga pendidik, (Wawancara, Senin, 14 Januari 2019).

Hal ini dilakukan dengan beberapa upaya diantaranya adalah sosialisasi dan Training of Trainer (ToT) pada tahun 2017 kepada setiap tenaga pendidik. Tujuannya adalah untuk memberikan pemahaman konsep Sekolah Ramah Anak pada setiap Sekolah yang nantinya dapat mengembangkan program tersebut di Sekolahnya masing-masing. Adapun peserta dari sosialisasi dan Training of Trainer (ToT) tersebut terdiri dari satu perwakilan setiap sekolah. Namun demikian kegiatan sosialisasi dan Training of Trainer (ToT) yang dilakukan belum maksimal dan menyeluruh karena keterbatasan anggaran dari Dinas Pemberdayaan Perempuan, Perlindungan Anak, Pengendalian Penduduk dan Keluarga Berencana maupun Dinas Pendidikan Kota Batu.

Selain itu, dilakukan pula Focus Group Discussion (FGD) yang diprakarsai oleh pihak SMPN 02 Kota Batu pada tanggal 5 Oktober 2018 yang lalu dan diikuti oleh 78 peserta terdiri dari 60 Guru SMP Negeri 02 Kota Batu, 14 tenaga kependidikan, 1 komite, dan 2 tenaga kantin untuk membahas keberlanjutan Program Sekolah Ramah Anak di sekolah tersebut. Hasil dari Focus Group Discussion (FGD) tersebut ialah adanya penandatanganan perjanjian antara Dinas Pemberdayaan Perempuan, Perlindungan Anak, Pengendalian Penduduk dan Keluarga Berencana Kota Batu yang bertujuan untuk mempertahankan dan mengembangkan Sekolah yang menyenangkan, ramah, tenang dan nyaman sebagai bentuk penerapan Program Sekolah Ramah Anak di SMPN 02 Kota Batu.

\section{Sumber Daya}

Menurut Edward III (dalam Widodo, 2017: 98) mengemukakan bahwa sumber daya mempunyai berperan penting pada penerapan kebijakan. Bagaimanapun jelasnya penyampaian ketentuan kebijakan jika pelaksana kebijakan tidak mempunyai sumber daya yang baik, maka penerapan kebijakan tidak efektif. Berdasarkan wawancara dan observasi di lapangan, sumberdaya belum sepenuhnya memenuhi standar dalam melaksanakan Program Sekolah Ramah Anak di SMPN 02 Kota Batu.

Pentingnya kesiapan sumber daya manusia untuk melaksanakan tugas dan fungsinya sangat menentukan keberhasilan suatu program atau kegiatan. Sumberdaya yang berkualitas meliputi pemahaman, pendidikan, pengetahuan dan pengalaman yang baik. Ketersediaan sumber daya khususnya tenaga pendidik masih perlu ditingkatkan mengingat sosialisasi dan Training of Trainer (ToT) yang pernah dilakukan tidak konsisten dan berkelanjutan sehingga berdampak pada rendahnya motivasi atau kemauan Sekolah-Sekolah untuk melaksanakan Sekolah Ramah Anak di Kota Batu. Selain itu, dua tahun terakhir di lingkup Pemerintah Kota Batu sering terjadi mutasi pegawai atau pemindahan jabatan khususnya di Dinas Pendidikan sehingga berdampak pada tenaga pendidik yang sebelumnya pernah mendapatkan sosialisasi dan Training of Trainer (ToT) dipindahtugaskan ke sekolah lain yang belum menerapkan Sekolah Ramah Anak memerlukan penyesuaian serta pemahaman tugas dan fungsinya.

Penyelenggaraan administrasi dalam sebuah organisasi publik atau Pemerintah tidak akan lepas dengan namanya keuangan. Indradi (2016: 28) menyatakan bahwa unsur keuangan atau anggaran menjadi sangat penting karena akan berdampak pada keputusan atau kebijakan yang diambil sehingga akan berpengaruh pada pembiayaan kegiatan administrasi dalam mencapai tujuan organisasi. Untuk saat ini pembiayaan Program Sekolah Ramah Anak di Kota Batu bersumber dari Dinas Pendidikan. Pada laporan tim Program Sekolah Ramah Anak SMPN 02 Kota Batu Tahun 2018 tercantum rencana anggaran dan biaya Program Sekolah Ramah Anak meliputi anggaran penyusunan Program dan 
kegiatan Sekolah Ramah Anak sebesar Rp. 300.000 dan sosialisasi Program dan kegiatan Sekolah Ramah Anak Rp. 300.000.

Namun demikian dana tersebut masih belum cukup untuk pembiayaan Program Sekolah Ramah Anak di SMPN 02 Kota Batu, mengakibatkan pihak Sekolah berinisiatif mengalokasikan dana bantuan operasional sekolah (BOS) untuk menambah biaya operasional program tersebut. Termasuk untuk memenuhi sarana dan prasarana penunjang yang sebetulnya masih belum sesuai dengan standar yang ditetapkan dalam Peraturan Menteri Pemberdayaan Perempuan dan Perlindungan Anak Nomor 8 Tahun 2014 Tentang Kebijakan Sekolah Ramah Anak, diantaranya adalah: kapasitas ruangan yang sesuai, peralatan belajar ramah, toilet yang bersih, saluran pembuangan tidak mencemari lingkungan, tempat cuci tangan, air yang bersih, bangunan aman dari bencana, ruang UKS, ruang konseling, ruang kreativitas, lapangan olahraga, area bermain, ruang perpustakaan, tempat ibadah, kantin sehat, tempat pembuangan sampah, media komunikasi, informasi dan edukasi.

\section{Disposisi}

Edward III (dalam Widodo, 2017: 104), diposisi merupakan sikap pelaksana untuk melaksanakan kebijakan sehingga terwujudnya tujuan kebijakan. Secara legalitas, pelaksanaan Program Sekolah Ramah Anak di Kota Batu masih mengikuti peraturan dari Kementerian Pemberdayaan Perempuan dan Perlindungan Anak. Saat ini pada lingkungan Pemerintah Kota batu belum terdapat petunjuk teknis pelaksanaan Program Sekolah Ramah Anak baik berupa Peraturan Daerah maupun Peraturan Walikota. Program Sekolah Ramah Anak di SMPN 02 Kota Batu merupakan inisiatif dari pihak Sekolah. Berikut penyampaian salah satu anggota pelaksana Program Sekolah Ramah Anak di SMPN 02 Batu dalam kutipan wawancara:

Untuk menjalankankan program Sekolah Ramah Anak ini, pihak sekolah mengacu pada instruksi dari kepala sekolah (Wawancara, Sabtu, 15 Desember 2018).

Atas instruksi kepala Sekolah tersebut kemudian dibentuk dan disahkan tim pelaksana 16 Juli 2018 untuk melanjutkan pelaksanaan program Sekolah Ramah Anak. Pelaksanaan Program Sekolah Ramah Anak yang diinisiasikan tersebut berakibatkan pada rendahnya kemauan Sekolah untuk melakukan pelaporan ke Dinas Pemberdayaan Perempuan, Perlindungan Anak, Pengendalian Penduduk dan Keluarga Berencana maupun Dinas Pendidikan Kota Batu selaku gugus tugas Kota Layak Anak. Hal tersebut juga dipengaruhi oleh tidak adanya peninjauan dan pengawasan dari gugus tugas Kota Layak Anak untuk memberi pengarahan, peninjauan kondis lapangan dan bimbingan teknis. Kurangnya kesungguhan pelaksana kebijakan ini menyebabkan proses pelaksanaan Program Sekolah Ramah Anak tidak efektif dan efisien, (Edward III dalam Widodo, 2017: 105).

\section{Struktur Birokrasi}

Menurut Edward III (dalam Widodo, 2017: 106), implementasi kebijakan menjadi tidak efektif karena ketidsesuaian susunan birokrasi. Struktur birokrasi meliputi susunan organisasi, wewenang, hubungan unit organisasi, dan hubungan antara organisasi dengan organisasi lainnya. Sekolah Ramah Anak di Kota Batu pada dasarnya leading sektornya pada Dinas Pemberdayaan Perempuan, Perlindungan Anak, Pengendalian Penduduk dan Keluarga Berencana namun Dinas Pendidikan ditugaskan pelaksana teknis.

Peraturan yang mendasari pelaksanaan program Sekolah Ramah Anak di Kota Batu mengacu pada Peraturan Kementerian Pemberdayaan Perempuan dan Perlindungan Anak Nomor 8 Tahun 2014 Tentang Kebijakan Sekolah Ramah Anak. Untuk saat ini di jajaran Pemerintah Kota Batu belum terdapat kebijakan turunan (Peraturan Walikota dan Peraturan Daerah) sebagai petunjuk pedoman teknis pelaksanaan program Sekolah Ramah Anak. Hal ini menyebabkan lemahnya koordinasi dinas- 
dinas untuk terlibat dalam mengsukseskan program tersebut belum bisa berjalan secara efektif, sehingga hal tersebut menjadi perhatian penting bagi Pemerintah Kota Batu apabila hendak mewujudkan Kota Layak Anak.

\section{Faktor Pendukung Implementasi Program Sekolah Ramah Anak}

Faktor pendukung pelaksanaan Program Sekolah Ramah Anak adalah motivasi, kemauan, kesediaan, kesadaran akan tanggung jawab yang muncul dari lingkungan SMPN 02 Kota Batu, sebagai berikut: Pertama adalah adanya aturan sebagai dasar untuk perlindungan terhadap hak anak kedepan yang lebih baik. Undang-Undang Nomor 35 Tahun 2014 Tentang Perlindungan Anak adalah merupakan kebijakan pemerintah yang patut untuk diapresiasi karena dikeluarkannya UndangUndang ini adalah sebagai bentuk nyata kepedulian Pemerintah untuk membangun generasi muda yang berkualitas. Kedua, kesepakatan bersama untuk menjamin masa depan anak yang lebih baik di Kota Batu melalui langkah-langkah mendasar seperti: sosialisasi, advokasi, fasilitasi secara terencana, terpadu dan berlanjut, menjamin legalitas keberadaan dan keberlanjutan Kota Layak Anak sebagai komitmen antara Pemerintah Daerah dan Dewan Perwakilan Rakyat Daerah (DPRD) Kota Batu menuju Kota Layak Anak.

\section{Faktor Penghambat Implementasi Program Sekolah Ramah Anak}

Adapun faktor penghambat dalam pelaksanaan Program Sekolah Ramah Anak di lingkungan Pemerintah Kota Batu adalah: Pertama, sosialisasi dan pelatihan yang tidak berkelanjutan. Kedua, ketersediaan sumber daya tenaga pendidik, anggaran, sarana dan prasarana dalam menunjang program ini masih tergolong rendah dan perlu ditingkatkan. Ketiga, kurangnya partisipasi setiap sekolah untuk mulai menggagas Program Sekolah Ramah Anak. Keempat, lemahnya kerjasama pemangku kepentingan dan pelaksana kebijakan.

\section{KESIMPULAN}

Implementasi Program Sekolah Ramah Anak di Kota Batu tergolong belum efektif. Jika dilihat dari segi komunikasi, sosialisasi dan Training of Trainer (ToT) yang pernah dilakukan tidak berkelanjutan sehingga berdampak pada rendahnya motivasi atau kemauan sekolah-sekolah untuk menerapkan Program Sekolah Ramah Anak di Kota Batu. Sumber daya berkualitas meliputi sumberdaya manusia yang memiliki pemahaman, pendidikan, pengetahuan dan pengalaman yang baik. Ketersediaan sumber daya khususnya tenaga pendidik masih perlu ditingkatkan mengingat sosialisasi dan Training of Trainer (ToT) yang dilakukan tidak berkelanjutan. Disposisi atau sikap pelaksana kebijakan untuk melaksanakan program secara sungguh-sungguh berpengaruh terhadap terwujudnya tujuan program. Pelaksanaan Program Sekolah Ramah Anak di Kota Batu berpedoman pada Peraturan Kementerian Pemberdayaan Perempuan dan Perlindungan Anak Nomor 8 Tahun 2014 Tentang Kebijakan Sekolah Ramah Anak mengingat belum adanya Peraturan Daerah terkait Program Sekolah Ramah Anak di Kota Batu. Struktur birokrasi, pembagian wewenang yang berdampak pada lemahnya kerjasama pemangku kepentingan dan pelaksana kebijakan.

Pelaksanaan Sekolah Ramah Anak di Kota Batu khususnya SMPN 02 didukung dengan adanya kesepakatan/komitmen Daerah menuju Kota Layak Anak dan aturan yang mendukung tegaknya perlindungan anak. Faktor penghambatnya yaitu sosialisasi dan pelatihan yang tidak berkelanjutan. Ketersediaan sumber daya tenaga pendidik, anggaran, sarana dan prasarana dalam menunjang program ini masih tergolong rendah dan perlu ditingkatkan. Rendahnya partisipasi setiap sekolah untuk mulai menggagas Program Sekolah Ramah Anak, dan lemahnya kerjasama pemangku kepentingan dan pelaksana kebijakan. 
REFORMASI

ISSN 2088-7469 (Paper) ISSN 2407-6864 (Online)

Volume 10 Nomor 1 (2020)

\section{DAFTAR PUSTAKA}

Agustino, Leo. 2012. Dasar-Dasar Kebijakan Publik. Bandung: CV. Alfabeta.

Arifina. 26 Maret 2019. Kekerasan Anak Dan Perempuan Di Kota Batu Naik Drastis. (https://radarmalang.id/kekerasan-anak-dan-perempuan-di-kota-batu-naik-drastis/), diakses pada 08 April 2019.

Editor KLA. Kabupaten/Kota Layak Anak. (http://www.kla.id/) diakses pada tanggal 18 Oktober 2018.

Indradi, Sjamsiar Sjamsuddin. 2016. Dasar-Dasar dan Teori Administrasi Publik. Malang: Intrans Publishing.

Nugroho, Riant. 2014. Kebijakan Publik Untuk Negara-Negara Berkembang: Model-Model Perumusan, Implementasi, dan Evaluasi. Jakarta: PT. Elex Media Komputindo.

Peraturan Menteri Pemberdayaan Perempuan dan Perlindungan Anak Nomor 8 Tahun 2014 Tentang Kebijakan Sekolah Ramah Anak

Peraturan Menteri Pemberdayaan Perempuan dan Perlindungan Anak Nomor 11 Tahun 2011 Tentang Kebijakan Pengembangan Kabupaten/Kota Layak Anak

Setyawan, Dody. 2017. Pengantar Kebijakan Publik. Malang: Intelegensia Media.

Undang-Undang Dasar 1945 Pasal 28C.

Undang-Undang Nomor 35 Tahun 2014 Tentang Perubahan Atas Undang-Undang Nomor 35 Tahun 2014 Tentang Perlindungan Anak.

Widodo, Joko. 2017. Analisis Kebijakan Publik: Konsep dan Aplikasi, Analisis Proses Kebijakan Publik. Malang: Media Nusa Creative. 